\title{
Manihot esculenta (Crantz)' Diversity Management by Peaysants in Pissa and Damara's Districts in the Central African Republic (A Comparative Approach)
}

\section{Gougodo De Mon-Zoni Julie Léancy ${ }^{1,2 *}$, Kosh-Komba $E^{1,3}$, Bombo-Yongo ${ }^{1}$, Zaman $\mathrm{M}^{5}$, Touckia $\mathrm{GI}^{6}$, Zinga $\mathrm{I}^{3}$, Semballa $\mathrm{S}^{3}$, Mololi $\mathrm{A}^{2}$, Batawila $\mathrm{K}^{4}$ and Akpagana $\mathrm{K}^{4}$}

${ }^{1}$ Plant and Fungal Biodiversity Laboratory, Faculty of Sciences, University of Bangui, Central African Republic

2Central African Agronomic Research Institute (CARI/ICRA), Bangui, Central

African Republic

3Laboratory of Biological and Agronomical Sciences for Development, Faculty of

Sciences, University of Bangui, Central African Republic

4Laboratory of Botanical and Ecological Plant, Faculty of Sciences, University of Lome, Togo

5International Atomic Energy Agency (IAEA), Vienna, Austria

6High Institute of Rural Development (HIRD/ISDR), University of Bangui, Central

African Republic

*Corresponding Author: Gougodo De Mon-Zoni Julie Léancy, Central African

Agronomic Research Institute (CARI/ICRA), Bangui, Central African Republic.
Received: February 22, 2021

Published: April 16, 2021

(C) All rights are reserved by Gougodo De

Mon-Zoni Julie Léancy., et al.

\begin{abstract}
Understanding knowledge and know-how of peasants' producers is important for the conducting efficient programs of agricultural development and appropriate research. The aim of this study is to analyze strategies of managing the diversity of cassavas by peasants through a comparative approach in the scale of the two districts that are characteristics of agroclimatic zones in the forest and in the savannah. An inquiry done with 420 peasants who are producers in 30 villages respectively in these district allowed censing Thirty-six (36) varieties among which 05 elites cultivated in the two districts. The various names given to the cultivars is linked to sociocultural facts, to introducers, to advantages obtained through cultivating manioc, to their origins, to the vegetative cycle and to the tastes. Highly significant differences have been observed in the number of cultivars in the two districts and vary from 2 to 13 per village (an average of 6) in the area of study. Variation between households is weak, from 1 to 3 cultivars (an average 2). The two districts have registered loss in cultivars. The number of cultivars that disappeared varies from 0 to 7 (an average of 3 ) per village. The rate of the diversity's loss has an average of $18.42 \%$ and varies between $0 \%$ to $75 \%$, according to the villages. This loss of diversity is mainly due to the cultivars' agronomic characteristics (long vegetative cycle, $34 \%$ ) and to the introduction of new varieties (25\%). Managing this culture is still traditional in the area of study, though many efforts have been done by institutions and spread and research services in the distribution of cuttings in areas where they are cultivated. The perception of associating cultures in the area of study is considered as a means of managing the cultivable space out crops and not that of managing the soil's fertility. Constraints of production (all over 8) can be reduced by using healthy cultivars and following technical advice. The study reveals the existence of an important diversity. Samples of collected cultivars gives 29 local accessions and 07 ameliorated varieties.
\end{abstract}

Keywords: Agroclimatics; Cultivar; Cassava; Socio-Cultural

Citation: Gougodo De Mon-Zoni Julie Léancy., et al. “Manihot esculenta (Crantz)’ Diversity Management by Peaysants in Pissa and Damara’s Districts in the Central African Republic (A Comparative Approach)". Acta Scientific Agriculture 5.5 (2021): 07-21. 


\section{Introduction}

The first target assigned to agricultural research has for a long time, been to produce enough crops in order to face demographic growth. Today, our food stands on a very limited number of cultures with only some ameliorated with a high yielding. Only 150 vegetal species are cultivated throughout the world and $4 \%$ furnish more than the half of food eaten [18]. This evolution has weakened agriculture and made poor our food regime. Today, agronomic research is the kernel part of global targets with the need of breading not only the whole planet but also to reduce poverty. That is why it must contribute to the long lasting development through a qualitative food stock and equality in the economy of production. Today, most of the world's agricultural soils in which there has been produced food are from farms [18].

In this fact, peasants' managing the diversity has to be taken into account particularly because it represents the diversity of plants cultivated and beyond that, agricultures' the diversity. Many phytogenetic resources in agriculture are the result of a selection and an amelioration done by farmers. Such is the case of cassavas that contributes fully in food security, creating jobs, the diversification in incomes in rural and urban areas, in the inner raw product (IRP) and at that, to fight against poverty [33]. It is the main culture in tropical and subtropical areas and is essentially practiced by familial exploitations [40].

In the Central African Republic, cassavas is the first food supply and plays an important role in households' food security, mainly among rural communities and constitutes the main food for more than $95 \%$ of Central Africans people [11]. This is generally a culture of subsistance for local consumption and the surplus is sold to earn money. It's annual national production is 2.6 million tones of fresh roots (10.8 $\mathrm{T} \mathrm{ha}^{-1}$ ) to 646.000 tones of raw de manioc/year [11] but does not satisfies the demand, although it is cultivated all over the country since the moist forest's area until the dry north's areas and is represented in the Central African Republic's scale by a great number of accessions [24]. Former works done on the cassavas by Zinga [42] and Kosh-Komba [25] have respectively shed a light on the impact of consequences of sickness on manioc's yield and the role of agricultural and social practices in the constitution and maintaining of a high diversity. Meanwhile, strategies and methods of peasant's managing the different agroclimatic areas of the country have not been exhaustively prospected or valorized. Many activities of agricultural development have failed when they tried to extend technical innovations without information about methods of production set by farmers and their technical and economical efficacy [35].

This failure is linked either to the under-estimation of performances of techniques locally elaborated, or to the deep adaptation of peasants' practices to their physical, technical, economical and social environment. In order to propose to farmers innovations corresponding to their needs, it would be better to be able to analyze: the milieu in which they produce; its' potentialities and its' characteristics' evolution; the present processes of production and their results (techniques used, corresponding tools, effects on the milieu, corresponding technical and economical results). Deep knowledge of sociocultural, economical and agronomical factors of this peasant's managing contributes to the valorization of theses local phytogenetical resources.

In order to contribute to food security in the Central African Republic by ameliorating the productivity and cassavas production, a good knowledge of practices and traditional knowledge is necessary, to tackle with the different agroclimatic areas sociocultural milieu. Such an approach can sustain national programs of amelioration. Thus, the aim of this study is to analyze strategies of peasant's management of the cassavas culture in a comparative approach in the Pissa and Damara districts' scale, which is a characteristic of agroclimatic areas in the forest and savannah. It concerns specifically: (1) censing the different cultivated accessions; (2) determining keeping strategies; (3) censing factors that determine the level of productivity of that culture.

\section{Methodology}

\section{Choosing areas of inquiry (localization of area of inquiry)}

The study was carried out from February to March 2020 in two districts among the 156 in the Central African Republic. The identified district, Pissa and Damara are characterized by two agroclimatic areas (forest and savannah) over the five that are found in the country. Thirty (30) villages over the 61 and 68 respectively situated in Pissa and Damara districts have been selected at random for the inquiries (Table 1). 
The Pissa commune

The Pissa commune (Figure 1) is situated in a forest area in the south-west of the CAR at $75 \mathrm{~km}$ from the capital city. It is the Guinean-forest climate which is found there with a rainfall varying from 1600 to $1800 \mathrm{~mm} /$ year [8]. Average annual temperatures in this region are situated between 23 and $26^{\circ} \mathrm{C}$, whereas the maximal annual temperature is $29^{\circ} \mathrm{C}$ and the minimal is $18^{\circ} \mathrm{C}$. The predominant vegetation is the forest one. The type of the soil is a little ferralitic desaturated (with a clay-sand texture) [8].

Table 1: List of villages prospected.

\begin{tabular}{|c|c|c|}
\hline District & Villages & Agro climatic areas \\
\hline Damara & $\begin{array}{c}\text { Ndara } 1 \\
\text { Binima } \\
\text { Ndara Centre } \\
\text { Manzèrè } \\
\text { Gbozo } \\
\text { Féré } \\
\text { Libi } \\
\text { Gboyo } \\
\text { Bossele } \\
\text { Ombella-bord } \\
\text { Tagoro } \\
\text { Mondjo } \\
\text { Gbaele } \\
\text { Leya } \\
\text { Grebeu } \\
\text { Gbago } \\
\text { Trangué } \\
\text { Ngamarengou Centre } \\
\text { Mbourouba } \\
\text { Ngouaka } \\
\text { Gbango } \\
\text { Pata } \\
\text { Gouzé } \\
\text { Nibi-finish } \\
\text { Mara } \\
\text { Mapou } \\
\text { Mara }\end{array}$ & Sudano-ubanguian \\
\hline
\end{tabular}

\begin{tabular}{|c|c|c|}
\hline Pissa & $\begin{array}{c}\text { Mbi } \\
\text { Sabé } \\
\text { Gbatambé } \\
\text { Bokoumou } \\
\text { Berengo } \\
\text { Diligban } \\
\text { Botoko } \\
\text { Bobangui } \\
\text { Bossabo } \\
\text { Bonguelé } \\
\text { Kapou } 1 \\
\text { Kalangoé } \\
\text { Bossongo Central } \\
\text { PK 55 } \\
\text { Pessèrè } \\
\text { Tongolo } \\
\text { Bossongo Café } \\
\text { Bogbate } \\
\text { Sakoulou } \\
\text { Bossongo } 3 \\
\text { Bombe } \\
\text { Boyama } \\
\text { Boyali } \\
\text { Mokotamba } \\
\text { Behon } \\
\text { Leboko } \\
\text { Magouga } \\
\text { Yaka }\end{array}$ & Forestial Guinean \\
\hline
\end{tabular}




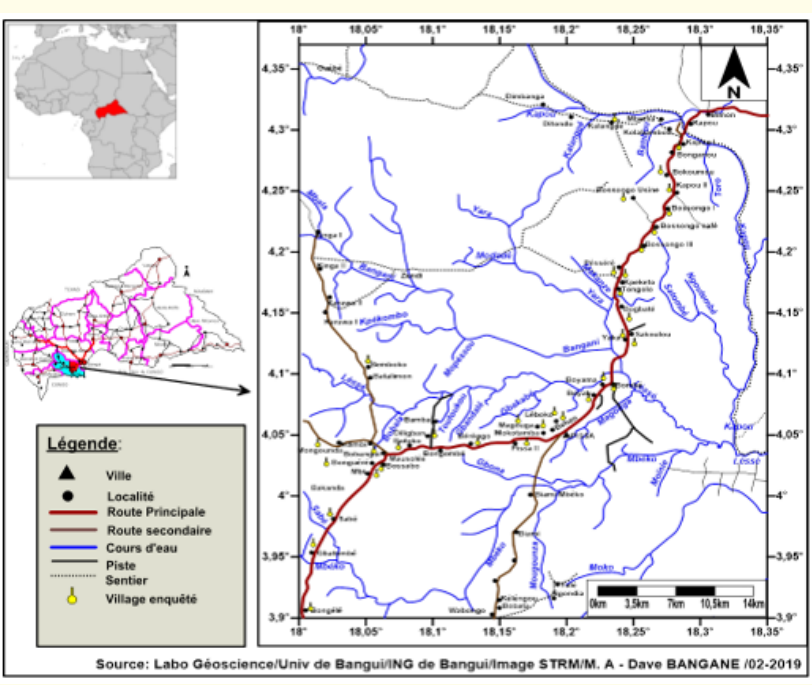

Figure 1: Map of the Pissa commune.

\section{The Damara commune}

Situated at $75 \mathrm{~km}$ in the Nord-East of Bangui in the Ombella M'poko prefecture, this locality (Figure 2) is the sudano-ubanguian agro climatic area with a rainfall varying from 1280 to $1519 \mathrm{~mm}$. La dominant vegetation is the little-tree savannah with a clay-sandysilt texture [8].

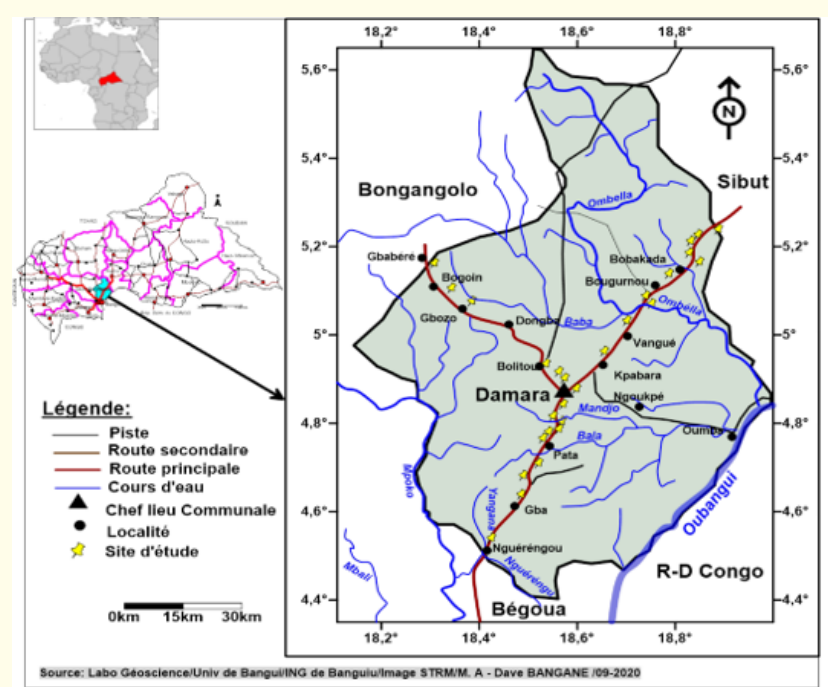

Figure 2: Map of the Damara commune.

\section{Collecting data}

A systematic census of the villages into the different districts has been done according to the Labé and Palm method [27] by being particularly interested in the big villages that produce more manioc. Their number varies from 07 to 10 per district. Peasants who produce cassavas in each village have been also been chosen whatever their sex, at random. Their number varies from 06 to 08 households per village. The statistical unit is farm represented by the Chief or one of the members. In each village, a previous meeting was held among Agricultural Technician advisers, research and local authorities. A great meeting then was organized during which targets and inquiry guidelines have been exposed. Entertainments have been carried out in local languages. The first step of the inquiry consisted in collecting information related to the villages and to cense cassavas cultivars. Collecting these data was done according to the participative research method. The second step of the inquiry is a series of structured entertainments under an inquiry leaflet and completed by non structured entertainments, done with 210 peasants by commune, that is to say a sample constituted of 420 producers.

\section{Data treatment and analyses}

The data obtained during the inquiries have been analyzed through the descriptive statistics (grade, percentage). The variance analysis (ANOVA) at the threshold (top) 5\% has been done on the cultivars' diversity per peasant thanks to the software XLSTAT-pro version 2013.5 .01 and the results have been presented as charts, graphics and figures. Simple correlations have been used in order to determine the percentage of variation between the number of ethnic groups and the diversity of accessions together with the variation between accessions on the verge of disappearing and the total number of accessions per village. $\mathrm{R}^{2}$ is the coefficient of correlation and allows knowing if there exists a linear association between two variables. It must be higher or equal to 0.5 . The Multiple Correspondence Analysis allows hierarchy factors which differentiate cultivars. The rate of loss or threat of cultivars (CLR) at the scale of is calculated according to Gbaguidi., et al. [21] to cpe with the formula CLR $=[(\mathrm{n}-\mathrm{k}) / \mathrm{N}] \times 100$ with $\mathrm{n}$ : number cultivars disappearing, $\mathrm{k}$ : number of cultivars newly introduced and $\mathrm{N}$ : the total of cultivars censed in the village. Constraints identified in each village and set into groups according to degree of importance have been hierarchized according to Orobiyi., et al. [34] in the area study on 
the basis of the average of three following parameters: number of villages in which the constraint is named (NTV); Number of villages in which the constraint is perceived as a main one (MC); number of villages in which the constraint is high or ranked among the first five (HC). For each of these parameters, a high value indicates an importance for the constraint. Thus, the importance of a constraint is determined by the following IMC $=(\mathrm{NTV}+\mathrm{HC}+\mathrm{CM}) / 3$.

\section{Results}

\section{Prospected villages' profiles}

In the area of study, men are the main cassavas producers (52\%). In the Pissa Commune, women are found to be those who are very interested $(67.7 \%)$ in cultivating cassavas whereas men prefer exploiting palm wine. Meanwhile, in the Damara Commune, cassavas is essentially cultivated by men $(67.5 \%)$. Women are rather implicated in post harvest activities.

On the linguistic level, 30 ethnic groups (Figure 3) have been identified; the most spoken dialect in Pissa is the Ngbaka language (55\%). Meanwhile, the Ngbaka-mandjia speakers are most numerous Damara (62\%). The same ethnic groups common to the two districts are: the Yakoma, the Ngbougou, the Ngbaka, the Mandjia, the Kaba, the Gbaya, the Banda and the Ali.

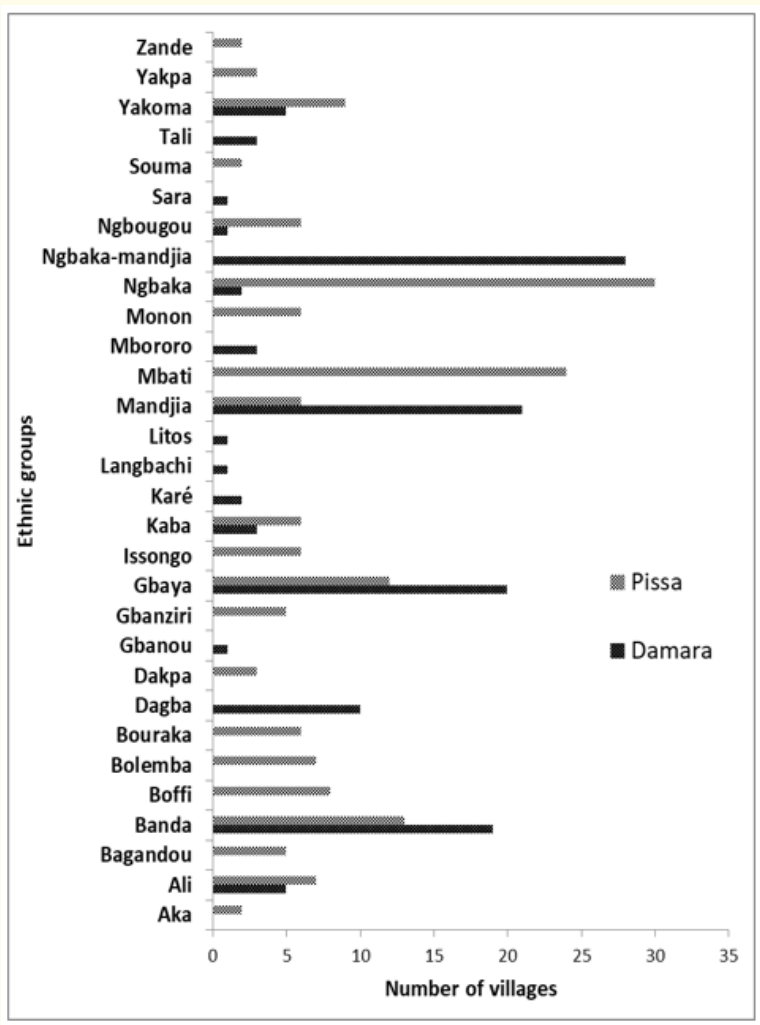

Figure 3: Number of different ethnic groups.
Different age brackets do exist (Figure 4). The greatest proportion is that of producers whose age varies between [35 - 45 ans] representing a frequency of $32.14 \%$. Young people whose age varies between [25-35] representing 34.9\% are most interested in cultivating cassavas in Damara. Whereas in the Pissa Commune, it is people aged [35 - 45 ans] (32.25\%) who are concerned.

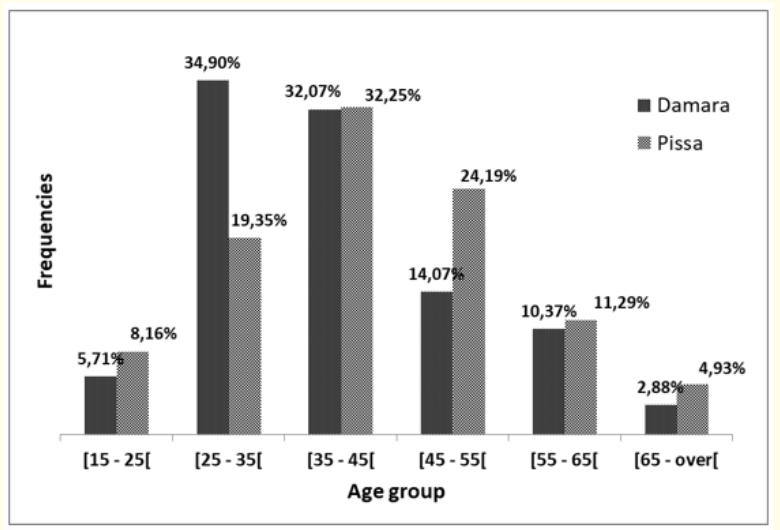

Figure 4: Producers' repartition per age brackets.

\section{Diversity of cultivated areas}

During the inquiries, 14 main cultures practiced have been signaled (Figure 5). Cassavas is the most cultivated resource, representing respectively by $24 \%$ and $19 \%$ on the two districts scale. This fact confirms the first rank hold by cassavas as the basis food in the Central African Republic. Cultures that come in the second position vary according to the commune. Either the plantain banana $(17 \%)$ is eaten in Pissa and corn $(22 \%)$ in Damara. This fact can be explained by food habits linked to sociocultural conditions on one hand and savannah and forest agroclimatic conditions on the other.

\section{Cultivating manioc}

Importance of cultivating cassavas for producers

Subjects' answers (100\%) show that cultivating cassavas has an importance and is diversely appreciated by peasants. It constitutes altogether a food source and of money income. This fact justifies the interest granted to cassavas culture considered as the basic food and a source of income in the Central African Republic. Meanwhile, $4.5 \%$ of producers in Damara say that they set forth selling compared to eating it against $1 \%$ in Pissa. 


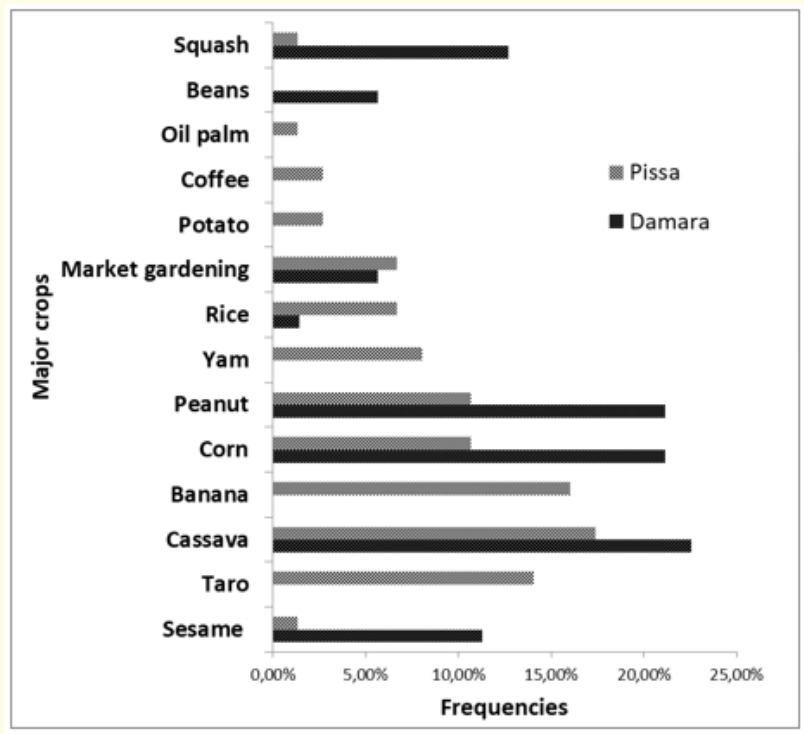

Figure 5: Relative frequencies of main cultures.

\section{Cassavas accessions cultivated}

Peasant's logic of giving names to accessions

From the 36 vernacular names that were signaled, it appears that there are 05 cultivars which bear the names of the origins of their source, 06 others refer to names or Christian names that were given and 02 others are those of national structures that distributed them.

The different namings are also linked to sociocultural facts, to advantages that cultivating cassavas gives, to their origins, to vegetative cycle and to tastes, often, used by the peasans producers in order to name cultivars. This logic in giving names to cultivars is the same in the two districts.

\section{Cultivars' diversity}

The Multiple Correspondence Analysis shows a contribution of $00 \%$ on the first way that sheds a light on the considered cultivars by peasants who are seen as elites. These cultivars are common to the two districts. These cultivars such as "Gabon", "Togo", "Icra" and "Six mois" are distributed by Institutions or research structures in charge of vulgarisation. The three first are certified as varieties and the last one is a local accession. Meanwhile, the second way shows a contribution of $100 \%$ which presents a great variability between local cultivars which are specific to each commune.

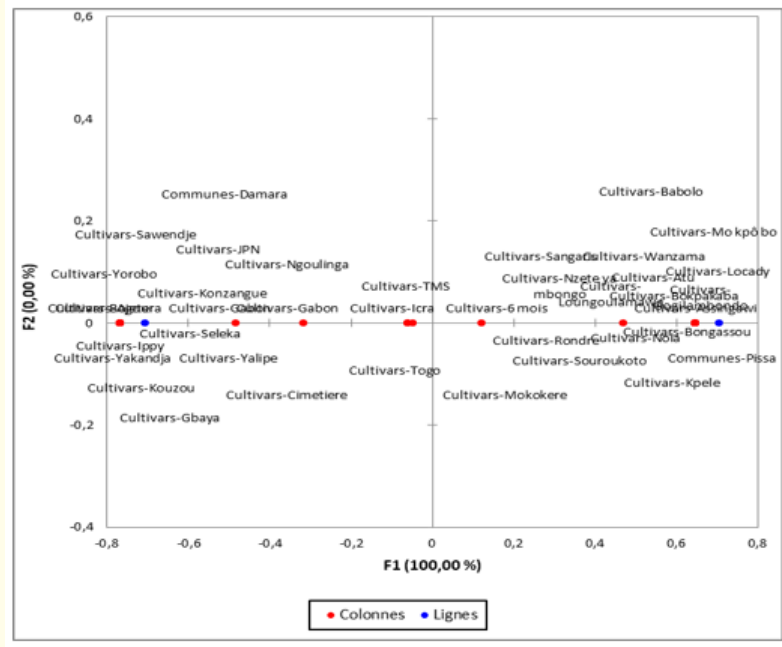

Figure 6: Correspondence factorial analysis between cultivars and prospected areas.

In reserve of synonymy, 36 cultivars have been signaled (Figure 7). Those considered as local are the most represented (29 cultivars). The 07 other certified as varieties are given structures of seeds' distribution.

Data of inquiry show a variation in the number of accessions cultivated in the 60 villages with a number varying from 02 to 13 (Table 2). The difference is highly significative ( $£=2 \mathrm{e}-16)$ threshold of $5 \%$ between villages of a same commune as well as between the two districts. The greatest diversity (13 cultivars) has been observed in Leboko and Boyama villages (Pissa) and the weakest (02 cultivars) in Liby, Ngouaka and Finish villages (Damara). Meanwhile, in households, the number of cultivars varies from 01 to 03 . Peasants cultivate accessions on the same field they hold.

Averages bearing different letters are significantly different at the threshold of $5 \%$.

There is no linear relation between ethnic groups' variables and the number of cultivars (Figure 8). The number of cultivars has no tendency to grow when there is a diversity of ethnic groups. Cloud points are not approximatively ranged at the line of equation $y=$ $0.8179 x$ with correlation coefficient $R^{2}=-0.389$. This means that there is no variation in the numbers of accessions by village when there are variations in the number of ethnic groups. 
Manihot esculenta (Crantz)' Diversity Management by Peaysants in Pissa and Damara's Districts in the Central African Republic (A Comparative Approach)

Table 2: Variation of various cultivars cultivated in villages and districts.

\begin{tabular}{|l|c|c|c|c|}
\hline Districts & Number of villages & $\begin{array}{c}\text { Cultivars minimum } \\
\text { value }\end{array}$ & $\begin{array}{c}\text { Cultivars maximum } \\
\text { value }\end{array}$ & $\begin{array}{c}\text { Cultivars average } \\
\text { number }\end{array}$ \\
\hline Pissa & 30 & 3 & 13 & $8 \mathrm{a}$ \\
\hline Damara & 30 & 2 & 6 & $4 \mathrm{~b}$ \\
\hline Area of study & 60 & 2 & 13 & 6 \\
\hline
\end{tabular}

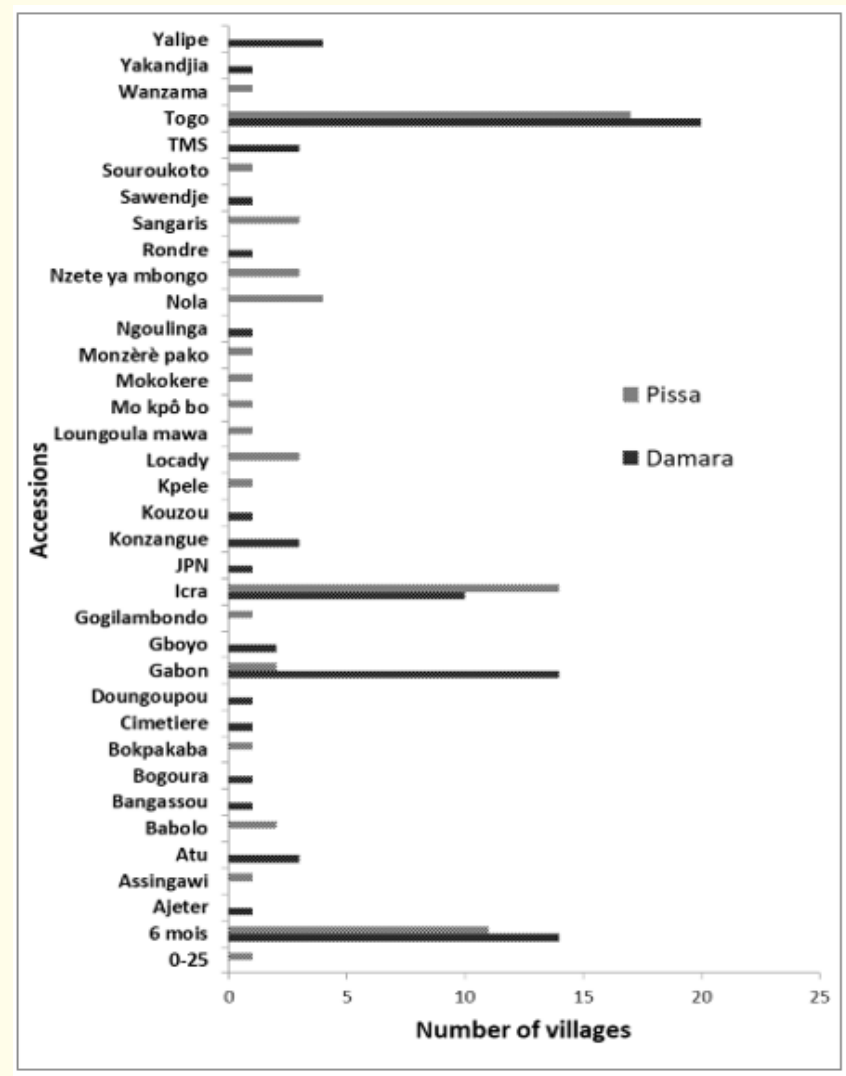

Figure 7: Cultivated accessions.

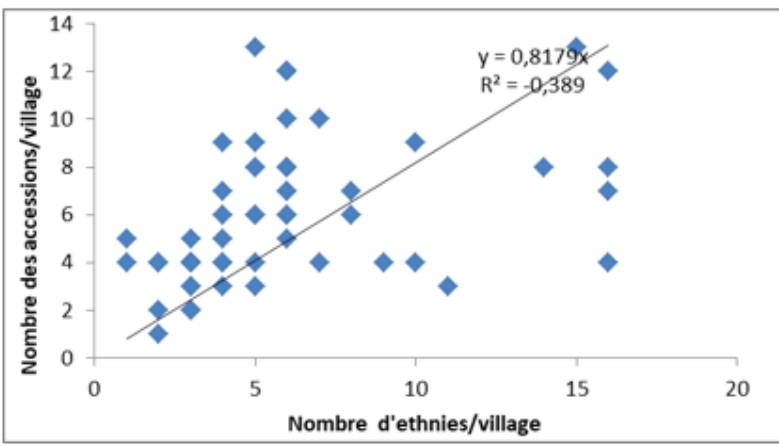

Figure 8: Linear correlation between ethnic groups and the number of cultivated accessions by village.
Figure 9 shows a series of variations observed in all of the accessions on the two ways of correspondence and explains 53.53\% of the total variability. This explains that there is no variation between accessions that are disappearing and those considered as yearned after by peasants in both districts. The short vegetative cycle, the high yielding and resisting to sicknesses are criteria used by peasants in order to make the choice of cultivars. Meanwhile, they are inclined to abandon those of a long cycle, of weak yielding, and having a sensibility to sicknesses. These criteria are particular to cultivars that are disappearing. Observations allowed understanding cultivars' characters have an influence as far as maintaining diversity is concerned.

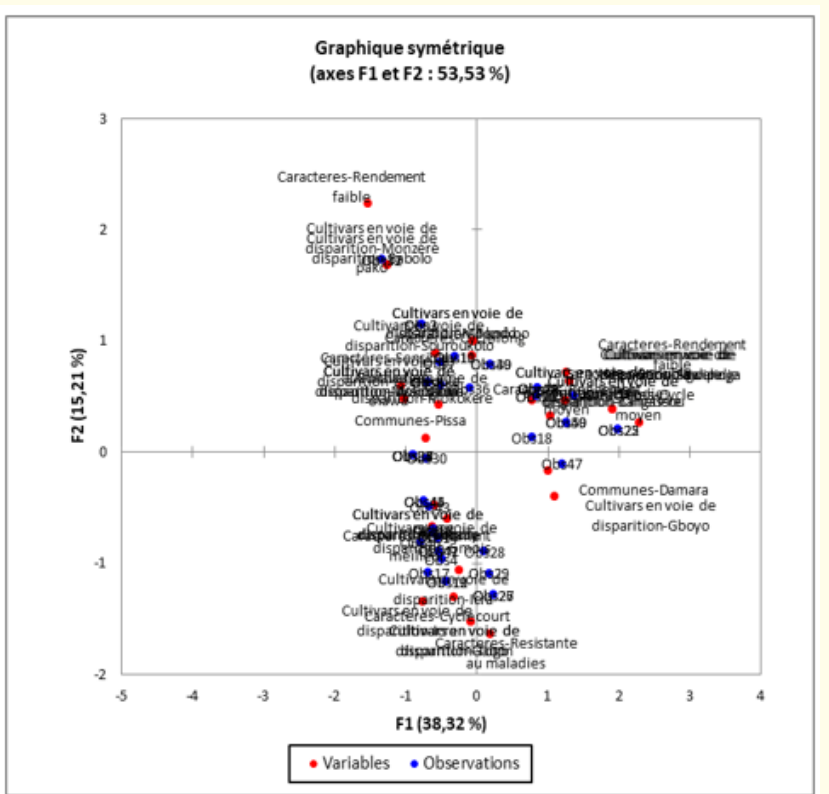

Figure 9: Cultivars' diversity per commune in relation with their characteristics.

There exists a variability in the vegetative cycle for all of the collected accessions (Figure 10). Most of them (58\%) are of a long cycle. In the Pissa commune, $61.90 \%$ of accessions are of a long cycle and 53.33\% in Damara. Accessions' vegetative cycle is one of the criteria of producers' choice of cassavas though there are other parameters of choice. 
Manihot esculenta (Crantz)' Diversity Management by Peaysants in Pissa and Damara's Districts in the Central African Republic (A Comparative Approach)

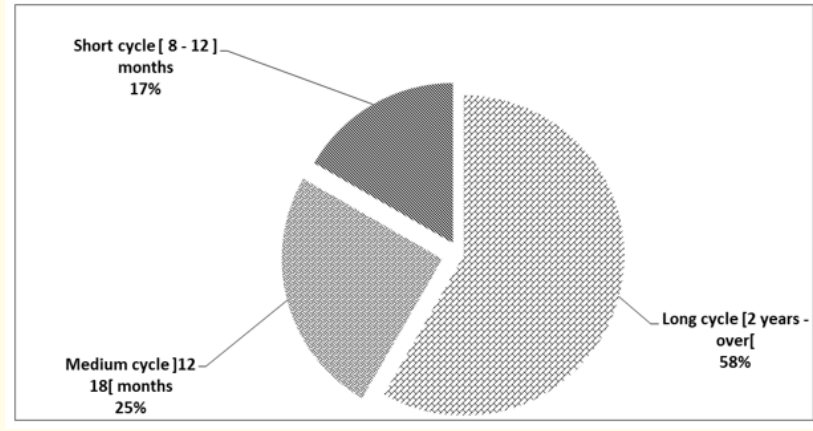

Figure 10: Cultivars' character: cultural cycle.

Figure 11 shows the character of accessions cultivated altogether by peasants and on the same field. The great proportion is that of bitter roots (78\%). In Damara, $83.3 \%$ of accessions are bitter and $72.22 \%$ are found in Pissa. Producers cultivate more bitter ac- cessions because most of products of consumption from cassavas come from the transformation of bitter roots which constitute the main source of income for peasants. Meanwhile, sweet roots are unearned after by rodents, most often used in families for direct consumption. For the peasant, the taste remains one the most important parameters that guide his choice.

It appears from this study, according to villages, that some accessions disappeared and some others are threatened to disappear (Table 3). Rates of loss vary from 0 to $75 \%$ with an average of $18.42 \%$. Damara commune expresses an important loss of diversity of $75 \%$ in Mondjo village and no loss has been registered in Gouze, Mbourouba, Biango, Gbouze, Gbozo, Gbango, Manzere Ombella-bord, Liby, Ngouaka, Finish Pata, Nguerengou, Ndara and Gbokoulou villages. Meanwhile in Pissa, Mokotamba village presents the highest rate in matter of loss of diversity (50\%).

Table 3: Rate of diversity's loss.

\begin{tabular}{|c|c|c|c|c|c|}
\hline \multirow{2}{*}{$\begin{array}{l}\text { Parameters } \\
\text { District }\end{array}$} & \multirow{2}{*}{ Villages } & \multirow{2}{*}{ CD } & \multirow{2}{*}{ CI } & \multirow{2}{*}{ NTC } & \multirow{2}{*}{$\begin{array}{c}\text { Rate of diversity } \\
\text { loss }\end{array}$} \\
\hline & & & & & \\
\hline \multirow{14}{*}{ Damara } & Binima, Tagoro, Gbayele, Imohoro, Fere & 2 & 2 & 4 & $0 \%$ \\
\hline & Ndara centre & 6 & 2 & 6 & $66.66 \%$ \\
\hline & Gouze, Mbourouba, Biango & 1 & 2 & 4 & $0 \%$ \\
\hline & Gbozo, Gbango, Manzere Ombella-bord & 0 & 2 & 4 & $0 \%$ \\
\hline & Malengapo, Gamakian & 2 & 1 & 5 & $20 \%$ \\
\hline & Liby, Ngouaka, Finish & 1 & 1 & 2 & $0 \%$ \\
\hline & Gboyo, Leya & 2 & 1 & 4 & $25 \%$ \\
\hline & Bossele & 3 & 2 & 3 & $33.33 \%$ \\
\hline & Pata, Nguerengou & 1 & 4 & 4 & $0 \%$ \\
\hline & Grebeu & 1 & 2 & 5 & $33.33 \%$ \\
\hline & Trangue & 1 & 2 & 3 & $0 \%$ \\
\hline & Mondjo & 3 & 0 & 4 & $75 \%$ \\
\hline & Gbokoulou & 1 & 3 & 5 & $0 \%$ \\
\hline & Ndara 1 & 1 & 4 & 6 & $0 \%$ \\
\hline \multirow{11}{*}{ Pissa } & Bossongo centre, Bossongo café, Bogbate, Botoukou, PK 55, Bombe & 2 & 2 & 6 & $0 \%$ \\
\hline & Leboko & 4 & 3 & 13 & $07 \%$ \\
\hline & Bossongo 3, Diligban & 4 & 3 & 9 & $11.12 \%$ \\
\hline & Pissa 2, Boyali, Bonguele & 4 & 3 & 6 & $16.66 \%$ \\
\hline & Bossabo, Gbatambe & 4 & 3 & 8 & $12.5 \%$ \\
\hline & Sabe, Yaka, Bobangui, Kapou 2 & 4 & 2 & 8 & $25 \%$ \\
\hline & Boyama & 5 & 2 & 13 & $23.07 \%$ \\
\hline & Kalangoe, Mbi & 4 & 2 & 7 & $28.57 \%$ \\
\hline & Bongombe & 2 & 1 & 3 & $33.34 \%$ \\
\hline & Mokotamba & 7 & 3 & 8 & $50 \%$ \\
\hline & Magouga, Sakoulou, Behon, Berengo, Kapou 1, Pessere & 1 & 2 & 10 & $0 \%$ \\
\hline
\end{tabular}




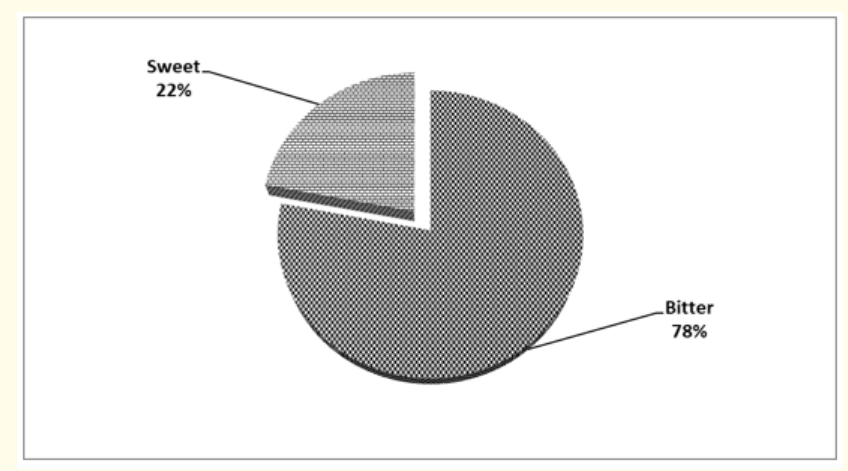

Figure 11: Cultivars' proportion related to cultivar's taste
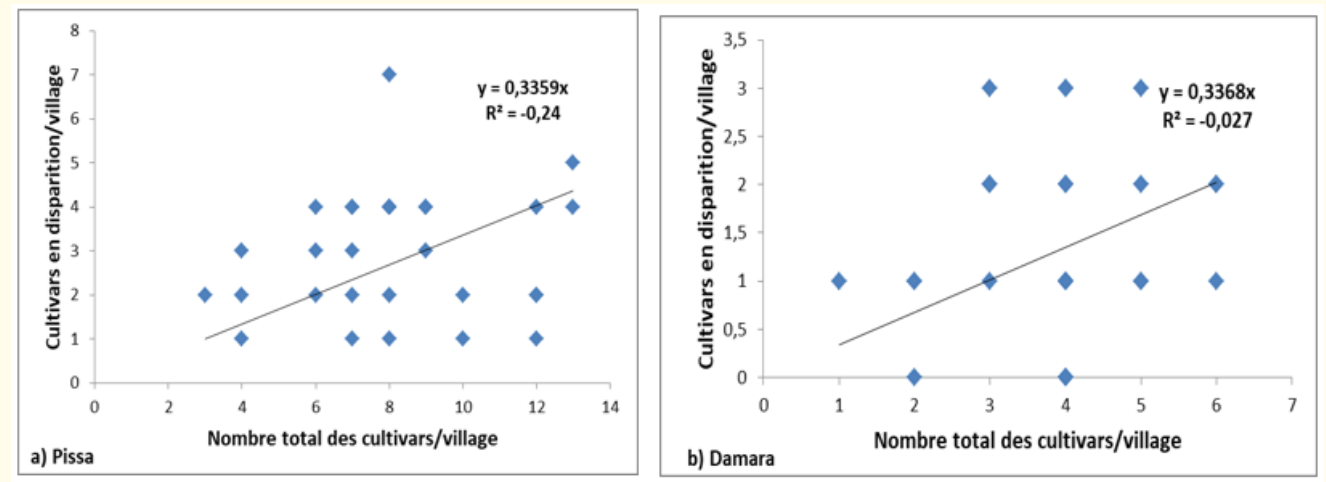

Figure 12: Correlation between the number of cultivars and cultivars threatened to disappear in the districts.

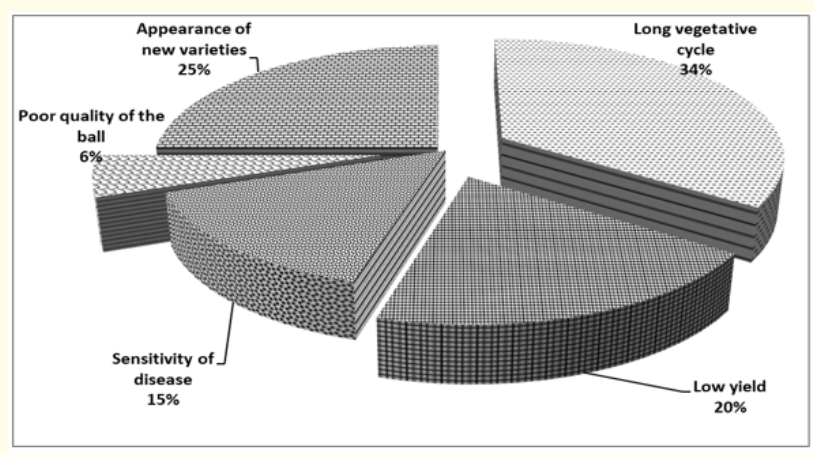

Figure 13: Causes of cultivar loss.
There is no correlation between the total number of accessions and accessions threatened to disappear (Figure 12). The Pissa commune as well as that of Damara presents respectively correlation's coefficients $R^{2}=-0.24$ (Figure 12a) and $R^{2}=-0.27$ (Figure $12 \mathrm{~b}$ ). This means that an important diversity would not explain genetic erosion's causes.

There are many causes mentioned by producers to justify genetic erosion. In the two districts, the main cause is due vegetative cycle which is relatively long (34\%), less appreciated, with $32.65 \%$ in Damara and $35.29 \%$ in Pissa. This fact is followed by the acquisition of new varieties (25\%) with 26.53\% in Damara and $23.52 \%$ in Pissa.

\section{Culture's managing stratégies}

The choice of soil is a fundamental approach for production for peasants. For the culture of manioc, the major criterion of reckognizing a better soil in Damara is justified by the presence of Laos' herb (Chromoelana odoranta) and earthworms' scraps, with respectively $35 \%$. The same fact has been done in Pissa concerning earth worms' scraps (25\%) and Laos' herb (18\%). At this fact, is added other considerations that farmers have for "Imperata" (Imperata cylindricum) and black soil with the same proportions as the previous criterion (Figure 14). Let's notice also that Notons in the two districts, $100 \%$ of the subjects ignore the interests of using the cultural rotative systems. 


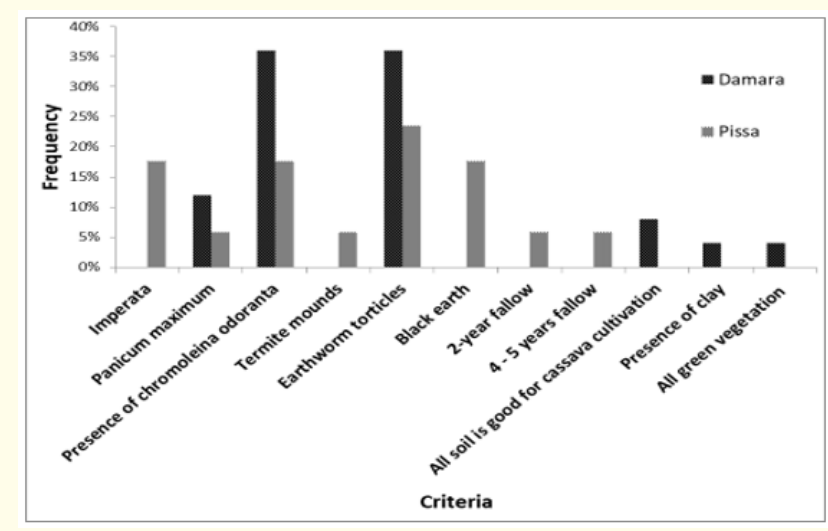

Figure 14: Criteria for recognizing a good soil for cultivating manioc.

Training based on appropriate cultural techniques is a fundamental precept to obtain the best agricultural yielding. Farmers in the great majority said that they did not have a technical training link to practical techniques for $80 \%$ of them in Pissa and $72 \%$ in Damara (Figure 15).

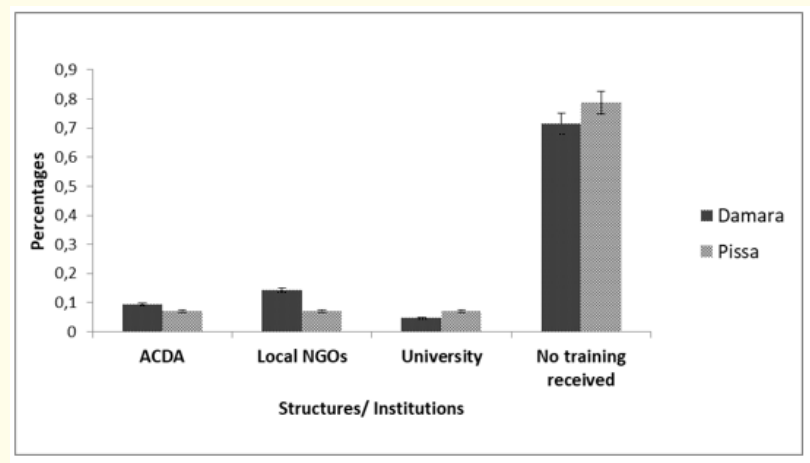

Figure 15: Technical training and supervising cultural areas.

Figure 16 shows that producers practice associated cultures. Cassavas is cultivated in association with other crops. Types of the most practiced associations are signaled in Damara: Manioc+Peanut+Corn (25\%) and Manioc+Peanut+Corn+Vegetables (20\%). Meanwhile in Pissa, types of associations (Manioc+Peanut+Corn, Manioc+Corn+Taro+Vegetable, Manioc+Corn, Manioc+Peanut+Corn, Manioc+Peanut+Courge and Manioc+Peanut) at equal proportion (18\%) are the most represented.

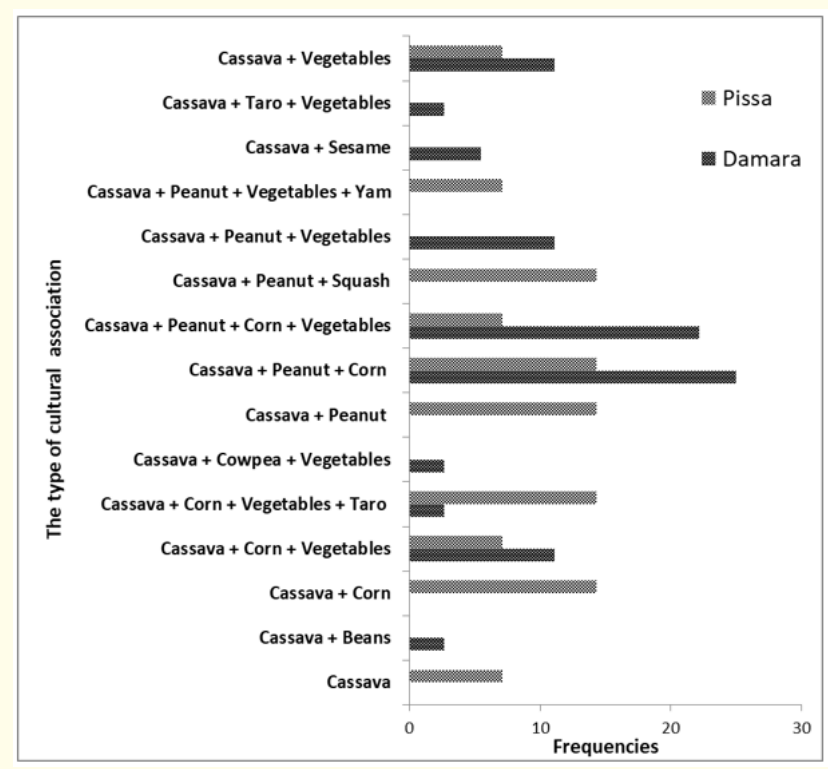

Figure 16: Frequency of association with cassavas at the basis.

\section{Traditional seed system and cement conservation}

Structures or services of agricultural vulgarisation such as ICRA, ACDA and some national NGO intervene in the distribution of cassavas cuttings to farmers. Though these helps, managing species of seeds remains traditional. Most of producers (90\%) after harvesting, keep a part of cuttings in order to use them again in the forthcoming campaigns. Most of the farmers (50\%) use cuttings coming from their heritage. Moreover, in order to be sure of the best quality or to have a new seed, $36.8 \%$ of producers who were interviewed use their friends' cuttings and $35.1 \%$ of producers buy from other producers.

\section{Constraint to the yielding}

Eight (8) constraints linked to cassavas yielding have been identified and hierarchized in the area of study (Table 4). The importance set in constraints is related to regions: the absence of mechanization, the non-sufficiency of early cultivars, the absence of technical training and following, sicknesses and rodents, and the low level of productivity are the most important in Damara commune. Meanwhile in Pissa, one can find: the least number of early and performant varieties, the lowering of productivity and roots' roting. 
Manihot esculenta (Crantz)' Diversity Management by Peaysants in Pissa and Damara's Districts in the Central African Republic (A Comparative Approach)

Table 4: Constraints linked to cassavas production.

\begin{tabular}{|c|c|c|c|c|c|c|}
\hline \multirow{2}{*}{$\begin{array}{l}\text { Locali- } \\
\text { ties }\end{array}$} & \multirow[t]{2}{*}{ Constraints } & \multicolumn{3}{|c|}{$\begin{array}{c}\text { Number of vil- } \\
\text { lage }\end{array}$} & \multirow{2}{*}{$\begin{array}{l}\text { Aver- } \\
\text { age }\end{array}$} & \multirow[t]{2}{*}{ Rank } \\
\hline & & TNV & MC & CM & & \\
\hline \multirow{6}{*}{ Damara } & Manual cultures & 30 & 26 & 30 & 28.66 & 1 \\
\hline & $\begin{array}{c}\text { Non-sufficiency of } \\
\text { early cultivars }\end{array}$ & 27 & 20 & 27 & 4.66 & 2 \\
\hline & $\begin{array}{c}\text { Lack of technical } \\
\text { training }\end{array}$ & 24 & 20 & 24 & 22.66 & 3 \\
\hline & $\begin{array}{c}\text { Sensibility to sick- } \\
\text { nesses }\end{array}$ & 23 & 20 & 21 & 1.33 & 4 \\
\hline & $\begin{array}{c}\text { Lowering of pro- } \\
\text { ductivity }\end{array}$ & 22 & 19 & 21 & 20.66 & 5 \\
\hline & Rodents & 20 & 18 & 19 & 19 & 6 \\
\hline \multirow{4}{*}{ Pissa } & $\begin{array}{c}\text { Non-sufficiency } \\
\text { of performant } \\
\text { varieties }\end{array}$ & 30 & 27 & 30 & 29 & 1 \\
\hline & $\begin{array}{c}\text { Lowering of pro- } \\
\text { ductivity }\end{array}$ & 25 & 20 & 23 & 22.66 & 2 \\
\hline & $\begin{array}{c}\text { Non-sufficiency of } \\
\text { early cultivars }\end{array}$ & 21 & 19 & 19 & 19.66 & 3 \\
\hline & Roots' roting & 18 & 13 & 15 & 5.33 & 4 \\
\hline
\end{tabular}

TNV: Total number of where constraint is signaled, MC: Number of villages where constraint is major (the most important), MC: Number of villages where constraint is major, that is to say among the first five ones.

\section{Discussion}

Diversity and importance of cultivating manioc

In the area of study, 36 cassavas cultivars are used for production. Commercialization and autoconsumption declared by $100 \%$ of the subjects in the two districts constitute the raisons of producing this crop. It is that shows that in the CAR, not only cassavas is the population's basic food, but also it plays an important rule in the battle against poverty by ameliorating the producers' income, such as the case of cassavas and yam which are the major cultures in the South and in the Centre of Benin [5]. Attributing vernacular to cultivars together with their significations are frequent practices in traditional societies. These practices have been signaled in many works. Missihoun., et al. [31] asserted that the local name is the basic unit that producers use in managing and selecting vegetal resources. The importance of this cultural factor in managing and maintaining biodiversity has also been reported by Manusset
[29]. At the end of the inquiries, the fact noticed in Pissa and also in Damara shows that in order to name cultivars, "names", "Christian names", "names from the original village", "anecdote" and others are used to designate the available sources. Meanwhile, Emperaire., et al.'s works [20] have shown that Amerindians on their part grant more importance to architectural traits and the cultivar is named by reference to the ending part of the plant. In Chad, Nadjiam., et al. [32] said that when a cultivar does not have a specific name, it is only qualified as a sweet or bitter cassavas in the different dialects. The most expanded qualifications of sweet are "koul", "sohol", "moreye" and for bitter cultivars "ade", "maguilira" and "ate". But this is not the case in Amazonia where sweet varieties are grouped under a unique name "macaxeiras" in the Centre and Nord-East regions of Brazil and bitter varieties bear the name "mandiocas" in the NordWest part of the country [20]. These modes of naming have also been action signaled on the varieties of sweet grains of sorghum in Burkina by Sawadogo., et al [38].

Most of the farmers, in their managing strategies, keep the necessary resources by maintaining the diversity in the field. This explains a bit the restricted basis of cultivars' diversity with an average 02 . The study has also revealed some high significant variations in the number of cultivars observed between villages (03 to 13 in Damara and 02 to 06 in Pissa) of the same commune and even between villages of different districts (02 to 13). Holders of one or many types of cultivars in a village are well known. These results are similar to Willemen., et al.'s works [41] that assert that farmers are conscious of the exact and precise number of cultivars existing in their villages. Taking into account of the number of cultivars in the village to evaluate the varietal diversity has also been reported on niebe's (beans') culture by Gbaguidi., et al [21]. Most of the censed cultivars (36) are local (29) and their number is weak, compared to other studies. 76 varieties have been counted during works done on cassavas by Elias [19] at Makushi Amerindians Makushi. This varietal diversity is higher according to Manusset [29] with 296 censed varieties in all of French Guyana. Nonetheless this difference, the local genetic potential highlighted in this study is important.

The average rate of loss of diversity observed in the area is relatively high (18.42\%) and needs to be particularly cared about. The zero rates observed in some villages in the two districts do not mean a best conservation, but rather that the maximum threshold of abandoning cultivars has been attained. Similar results have 
been observed on millet [16], yam [17,28], niebe (beans) [21] and pepper [34]. Reasons that explain the genetic erosion can only be explained by an important diversity in the villages or commune, such as the study realized by Kosh-Komba., et al. [26] on such species as Musa in Pissa commune. Other factor scan be the cause.

\section{Managing mode of cultures}

Farmers set many strategies and agricultural practices to manage cassava culture because they are always victims of lowering of the yielding sometimes linked to agroclimatic conditions, soil, added to these practices linked to sociocultural milieux. In this study, some variations are observed in conformity with districts that characterize forest and savannah areas. It is this way that Pouya., et al. [36] and Ravonjiarison., et al. [37] have mentioned farmers' adaptative behavior in front of factors of agricultural yield. The diversity of strategies cultural practices that are observed in the area would be due to socioeconomic conditions and to farmers' knowhow who adjust different managing modes of agricultural spots to local conditions. In this perspective, the inquiry revealed among the strategies used by farmers, the practice of cultural associations and the mode of choice of culture soil. Concerning the cultural associations, farmers perceive them as newly adopted practices that would allow managing well the cultivable spot. These results are strengthened by Adjahossou's., et al. [2] reported by Apko., et al. [7] who indicated that cultural association corn/peanut, allows to avoiding an additional ploughing of 0.2 to $0.6 \mathrm{Ha}$ of natural vegetation against 1.5 for the association corn/manioc/groundnut. Also, Bambara's., et al. [12] works on ameliorating a system of cultures associating cereal and vegetables gives birth to an augmentation of yielding grains from 34 and 26\% respectively for sorghum and niebe (beans) and a surplus of yield in grass from $26 \%$ and $45 \%$ for fans. Charles njomaha [15] in the North of Cameroon asserts that the choice of technical routes is done particularly in relation to the estimated yield. The aim is to have a sure, with a minimum of expenses. Meanwhile, at the level of the two district, farmers have declared during the inquiries that they ignore that there exist some associations such as those done at the basis of vegetables would ameliorate cultures' yielding which are associated to them. This fact would allow them guide their system of cultural association. Such types of association as: manioc+corn and manioc+corn+taro practiced in Pissa commune would not benefit as far as cassavas roots' yielding is concerned because all these cultures wear out the soil.
Some criteria are used by farmers in order to make cultural areas' choice and to solve fertility soils' problem. The presence of earthworms' scraps and that of Laos' herb are the most used in Damara. Meanwhile in Pissa, the presence of black soil and that of Imperata cylindrica added to the previous are the main indicator signs of the fertility of soil used. Farmers cultivate at the same time sweet and bitter cultivars, and they do this on the same field. This fact has been signaled by Bradbury., et al. [13] in a study done on cassavas where all the population in the South of Chad, as well as that population on the lower part of the Amazonian Bass in cultivate at the same time sweet and bitter accessions. Meanwhile, a contrary practice has been observed in South America where indigenous groups in the West of Amazonia cultivate only the sweet manioc. The managing mode is relative to phytogeographic areas and to sociocultural aspects.

As far as cultural rotations are concerned, cultural successions executed by farmers in the two districts do not obey, according to them, to managing targets of the fertility of soils. For them, this practice is specific to farmers in the areas where cotton is cultivated and that cereals are cultivated after cotton in order to benefit from the back effect of mineral manure put into the during the former culture of cotton. These results are not conformed to those obtained in Kenya by Tittonell., et al. [39], indicating that on poor soils, farmers cultivate only plants they judge able to produce in harsh conditions. To select cultivars, farmers use three priority criteria: precocity, productivity and resistance to sicknesses. These criteria of choice are identical to the two districts and identical to those reported by Kombo., et al. [22,23] in a study done on manioc. But ehri importance varies a lot because constraints linked to the cassavas culture differ according to areas. Subjects' answers to the ways of obtaining cuttings show that the same cuttings go from a field to another. This fact has also been reported by Abdou., et al. [1] in a study done on onion and he asserts that managing the diversity of genetic resources is affected by modes of exchange, of transmission and of selecting seeds. Different modes of exchanges have also been signaled in the case of niebe (beans) [9], of cassavas [30] and of yam [10]. This study has revealed that cuttings are always exchanged, granted and sometimes sold. The weak level of introducing accessions by specialized institutions in the two districts is at origin of the weak number (07) of the censed ameliorated cultivars. 


\section{Constraints linked to cassavas production}

Cassavas production is hindered by many constraints which are all directly or indirectly of agronomic reasons. Meanwhile, the importance put on constraints vary in function of district. The absence of mechanization constitutes the most important constraint signaled by farmers in Damara. Different cultural operations are only done manually. This fact obliges farmers to cultivar on little areas varying from 0.25 to 01 ha. Meanwhile in Pissa, the main constraint is the weak number of performant varieties. Data of inquiries in Damara do not match with Aigbe and Remison's [6]; Adjei-Nsiah's [3]; Kombo., et al.'s. [23]; Adriano., et al.'s [4], showing that the nonsufficiency of performant varieties in agriculture constitutes then the most important constraint than agronomic research has to be able to develop many performant varieties in order to help farmers to tackle with nefast effects of climatic variabilities and to sicknesses. This information matches with that in Pissa. The emergence of this constraint can be explained by militaro-political conflicts and to them, can be added the peasants' equipment management. As for the non-sufficiency of early varieties, the lack of technical training, rodents and sicknesses signaled as major constraints; sending agents of vulgarization on the ground and the use of techniques of culture in vitro through micropropagation can be used in order to multiplication these selected varieties [14].

\section{Conclusion}

The target aimed at through this study is to analyze peasants' managing strategies of cassavas culture in a comparative approach in Pissa and Damara districts, which are characteristic to agroclimatic areas of forest and savanah in the Central African Republic.

At the end of the results obtained, it appears that this resource contributes to food security. The named diversity is significant in the areas of study but meanwhile victim of some constraints, which among many others, threats of description (genetic erosions); last of their vegetative cycle relatively long; introducing new varieties. Local names given to accessions are for most of them characterized by their origins, cultural cycles, yielding, technological and organoleptically characteristics, color, shape and aspect of different parts of the plant. Choice of accessions is done in function of peasants' specific needs.

Farmers' strategies of maintaining this diversity are based on conservation in situ. Managing soil fertility through the system of cultural associations and rotating cultures seems to be unknown to peasants in the two districts. The identified constraints constitute an obstacle to cassavas culture.

Information coming from this study clearly shows that developing a long lasting management programme of agricultural biodiversity must take into account of farmers' strategies of managing phylogenetic resources and considering populations' sociocultural aspects and areas' agroclimatic characteristics. This study limited to savanah and forest areas can be done in other agroclimatic areas and sociocultural milieux of the country.

\section{Acknowledgements}

This work was funded by grants from the International Atomic Energy Agency (IAEA).

\section{Bibliography}

1. Abdou R., et al. "Taxonomie locale et analyse des critères des paysans pour caractériser les différents écotypes d'oignons (Allium cepa L.) du Niger". Cahiers Agricultures 23.3 (2014): 166-176.

2. Adjahossou VN., et al. "Evaluation de l'intensité territoriale de deux systèmes de cultures associées modérément fertilisées au SudBénin". International Journal of Biological and Chemical Sciences 7.6 (2013): 2233-2247.

3. Adjei-Nsiah S. "Evaluating sustainable cropping sequences with cassava and three grain legume crops: Effects on soil fertility and maize yields in the semideciduous forest zone of Ghana". Journal of Soil Science and Environmental Management 3.2 (2012): 49-55.

4. Adriano SR., et al. "Relative contribution of biotic and abiotic factors to the population density of the cassava green mite, Mononychellus tanajoa (Acari: Tetranychidae)". Experimental and Applied Acarology 276 (2013): 1496-1505.

5. Agre P., et al. "Diversité et évaluation participative des cultivars du manioc (Manihot esculenta Crantz) au centre Bénin". International Journal of Biological and Chemical Sciences 9.1 (2015): 388-408.

6. Aigbe S and Remison SU. "The influence of growth stages on cassava tuberous root rot in different ecological environments". Phytopathology and Plant Protection 43.12 (2010): 1243-1248. 
7. Apko M., et al. "Evaluation de la performance des pratiques de gestion de la fertilité des sols dans le bassin de la rivière Okpara au Bénin". European Scientific Journal 12.33 (2016): 370-390.

8. Atlas de la République Centrafricaine". Edition Enfance et Paix, Kinshasa (2008): 169.

9. Baco MN., et al. "Evaluation des pratiques de gestion de la diversité du niébé (Vigna unguiculata): une tentative méthodologique expérimentée au Bénin”. Cahiers Agricultures 17.2 (2008): 183-188.

10. Baco MN. "Les pratiques de gestion de la diversité variétale de l'igname au Bénin". Agridape 30.1 (2014): 3.

11. Ballot C., et al. "Amélioration des rendements de la culture du manioc (Manihot esculenta Crantz, Euphorbiales, Euphorbiaceae) par les terres de termitières dans la zone de savane de Damara en République Centrafricaine". Revue Marocaine des Sciences Agronomiques et Vétérinaires 4.2 (2016): 40-53.

12. Bambara D., et al. "Association céréale/légumineuse et intégration agriculture-élevage en zone soudano-sahélienne". Cahiers Agricultures 17.3 (2008): 297-301.

13. Bradbury EJ., et al. "Geographic differences in patterns of genetic differenciation among bitter and sweet manioc (Manihot esculenta subsp. esculenta; Euphorbiaceae)". American Journal of Botany 100.5 (2013): 857-866.

14. Cacaï GH., et al. "Effets de différentes combinaisons hormonales sur l'organogenèse in vitro de quelques cultivars locaux et variétés améliorées de Manihot esculenta Crantz (manioc Euphorbiaceae) cultivées au Bénin". International Journal of Biological and Chemical Sciences 6.4 (2012): 1593-1160.

15. Charles Njomaha. "Durabilité des systèmes de culture dans l'Extrême-Nord Cameroun". Actes du Colloque 27-31 (2002): 10.

16. Dansi A., et al. "Diversity conservation and related wild species of Fonio millet (Digitaria spp.) in the northwest of Benin". Genetic Resources and Crop Évolution 57.6 (2010): 827-839.

17. Dansi A., et al. "Production constraints and farmers' cultivar preference criteria of cultivated yams (Dioscorea cayenensis - D. rotundata complex) in Togo". International Journal of Applied Biology and Pharmaceutical Technology 4.2 (2013): 191199.
18. Didier B and et Hocdé $\mathrm{H}$. "Gestion paysanne de la diversité: un defi pour les agricultures du sud". Dossier de presse RTRA agronomie (2006): 51.

19. Elias M. "Le manioc chez les Makushi: une richesse à valoriser. In les Peuples des Forêts Tropicales Aujourd'hui (vol. 4), Grenand P (ed)". Région Caraïbes Guyanes Bélize Programme APFT: Bruxelles (2000): 201-221.

20. Emperaire L., et al. "Approche comparative de la diversité génétique et de la diversité morphologique des maniocs en Amazonie (Brésil et Guyanes)". Les Actes du BRG 4 (2003): 247-267.

21. Gbaguidi AA., et al. "Diversity and agronomic performances of the cowpea (Vigna unguiculata Walp.) landraces in Southern Benin". International Research Journal of Agricultural Science and Soil Science 3.4 (2013): 121-133.

22. Kombo GR., et al. "Diversity of cassava (Manihot esculenta Crantz) cultivars and its management in the department of Bouenza in the Republic of Congo". Genetic Resources and Crop Evolution 59.8 (2012): 1789-1803.

23. Kombo GR., et al. "Diversity of cassava (Manihot esculenta Crantz) cultivars and its management in the department of Bouenza in the Republic of Congo". Genetic Resources and Crop Evolution 59.8 (2012): 1789-1803.

24. Kosh-Komba E., et al. "Diversité agromorphologique de Manihot Esculenta Crantz (Euphorbiaceae) cultivée dans trois zones agroclimatiques en République Centrafricaine (RCA)". European Scientific Journal 10.3 (2014): 365-380.

25. Kosh-komba E. "Gestion paysanne, diversité agro morphologique et génétique de Manihot esculenta Crantz cultivé en République Centrafricaine". Thèse. Togo (2013): 123.

26. Kosh-Komba E., et al. "Managing various Musa varieties cultivated in Pissa district in the Central African Republic". Academic Journals, African Journal of Agricultural Research 17.2 (2021): 255-267.

27. Labé V and Palm R. "Méthodes et techniques. Statistique, empirique, formelle: quelle enquête pour la collection d'informations sur les exploitations agricoles?" Cahiers Agricultures 8.5 (1999): 397-404.

28. Loko YL., et al. "Current status and spatial analysis of Guinea yam (Dioscorea cayenensis Lam. -D. rotundata Poir. complex) diversity in Benin". International Research Journal of Agricultural Science and Soil Science 3.7 (2013): 219-238. 
29. Manusset S. "Proposition pour une clé d'identification des variétés de manioc chez différents groupes culturels en Guyane française". Antropo 11 (2006): 61-73.

30. McKey D., et al. "Gestions locales et dynamiques régionales de la diversité variétale du manioc en Amazonie". Genetics Selection Evolution 33 (2001): 465-490.

31. Missihoun AA., et al. "Gestion traditionnelle et statut des ressources génétiques du sorgho (Sorghum bicolor L. Moench) au Nord Ouest du Bénin". The International Journal of Biological and Chemical Sciences 6.3 (2012): 1003-1018.

32. Nadjiam Djirabaye., et al. "Pratiques paysannes de gestion des cultivars de manioc (Manihot esculenta Crantz) au Sud du Tchad". The International Journal of Biological and Chemical Sciences 10.3 (2016): 1098-1113.

33. Nassar N and Ortiz R. "Breeding cassava to feed the poor". Scientific American 302.5 (2010): 78-84.

34. Orobiyi A., et al. "Chili (Capsicum annuum L.) in southern Benin: production constraints, varietal diversity, preference criteria and participatory evaluation". International Research Journal of Agricultural Science and Soil Science 3.4 (2013): 107-120.

35. OUA. "Projet Modèle Loi Nationale sur la Sécurité en Biotechnologie (2002): 44.

36. Pouya MB., et al. "Pratiques actuelles de gestion de la fertilité des sols et leurs effets sur la production du cotonnier et sur le sol dans les exploitations cotonnières du Centre et de l'Ouest du Burkina Faso". Cahier Agriculture (2013): 282-292.

37. Ravonjiarison N., et al. "Savoirs locaux et stratégies paysannes autour de la fertilité des sols au lac Alaotra, Madagascar". Étude et Gestion des Sols 25 (2018): 29-41.

38. Sawadogo N., et al. "Caractérisation agromorphologique des sorghos à grains sucrés (Sorghum bicolor (L.) Moench) du Burkina Faso". The International Journal of Biological and Chemical Sciences 8.5 (2014): 21832197.

39. Tittonell P., et al. "Exploring diversity in soil fertility management of smallholder farms in western Kenya". Agriculture, Ecosystemaïs and Environment 110 (2005): 166-184.

40. Turyagyenda L., et al. "Physiological and molecular characterization of drought responses and identification of candidate tolerance genes in cassava". African Crop Science Journal 20.1 (2013): 15-30.
41. Willemen L., et al. "Spatial patterns of diversity and genetic erosion of traditional cassava (Manihot esculenta Crantz) in the Peruvian Amazon: An evaluation of socioeconomic and environmental indicators". Genetic Resources and Crop Evolution 54.7 (2007): 1599-1612.

42. Zinga I., et al. "Epidemiological assessment of cassava mosaic disease in Central African Republic reveals the importance of mixed viral infection and poor health of plant cuttings". Crop Protection 44 (2013): 6-12.

\section{Assets from publication with us}

- Prompt Acknowledgement after receiving the article

- Thorough Double blinded peer review

- Rapid Publication

- Issue of Publication Certificate

- High visibility of your Published work

Website: www.actascientific.com/

Submit Article: www.actascientific.com/submission.php

Email us: editor@actascientific.com

Contact us: +919182824667 